\title{
The Impact of Technology Based Self Service Banking Dimensions On Customer Satisfaction
}

\author{
Rajiv Sindwani ${ }^{1}$ and Dr Manisha Goel ${ }^{2}$ \\ Department of Management Studies, \\ YMCA University of Science \& Technology, Faridabad, India
}

\begin{abstract}
The technology based self service banking (TBSSB) refers to automated banking services that customer avail in self service mode using various electronic banking channels, without any interaction with bank employees. This paper investigates the relationship between key dimensions (factors) of TBSSB service quality and Customer Satisfaction. A structured questionnaire was formulated by identifying and adapting attributes on the basis of past studies on service quality of automated services and customer satisfaction. Data was collected from sample of bank customers in India. The collected data was divided into two subsamples of equal size. The TBSSB service quality and customer satisfaction dimensions were identified by conducting an exploratory factor analysis (EFA) on the half of the collected data using SPSS 16.0 software. Factor structure was confirmed by conducting confirmatory factor analysis (CFA) using AMOS 20.0 software on the remaining half of the collected data. The proposed model was empirically tested for unidimensionality, reliability, and validity. AMOS 20.0 was also used to examine the link amid TBSSB service quality and Customer Satisfaction by testing hypotheses using structural equation modeling (SEM). This study may help banks' management to investigate the customers' quality perceptions about TBSSB services, thereby helping banks to formulate strategies to improve the quality of service and customer satisfaction.
\end{abstract}

\section{KEYWORDS}

Exploratory factor analysis (EFA), confirmatory factor analysis (CFA), Technology based self service banking (TBSSB), structural equation modeling (SEM), India

\section{INTRODUCTION}

Today almost all commercial Public, Private or Foreign National banks are offering automated self service banking services [1]. As the products offered by the banks are more or less identical, banks are trying to have edge over rivals on other parameters which may enhance customer satisfaction and loyalty. This is because organizations having satisfied and loyal customers will be able to survive and compete in future [2-3]. Today almost every bank is using technology to deliver services to customers. With time automated banking services acceptance is increasing among bank customers. This is apparent from the reduction in transactions through branches and the increase in the transactions through automated self service modes in many of the banks. Both researchers and managers are equally interested in managing service quality as it affects customer satisfaction, loyalty and business performances $[2,4,5]$. Study of service quality of automated banking services is required because it leads to competitive advantage and customer attractiveness $[4,6]$. Most of the studies on technology based self service banking quality covers only one of the automated banking channels. In these studies service quality has been measured taking into consideration particular channel like ATM banking, Internet banking and tele banking. As Customer may use more than one automated banking channel, so limiting research to only one channel will not give the overall representation of automated self service banking service quality. To get the comprehensive picture, in the present study broad attributes affecting technology based self service banking (TBSSB) service quality are grouped into dimensions and their relationship with Customer Satisfaction is studied. 
The remainder of the paper is organized as follows: The first sections present the literature review on automated banking service quality and customer satisfaction. Next, the paper discusses the research methodology used in the paper as well as the survey instrument used for data collection. Finally, results are presented along with conclusion.

\section{LITERATURE REVIEW}

\subsection{Automated Banking Service Quality}

With time numerous models have been developed for measuring service quality. In literature, main conceptualizations of service quality are either based on the disconfirmation between perception and expectation [7,8,9], or performance only approach [10]. [11] found that performance-only measure is more reliable and stronger indicator of service quality than performance-expectations measure. A study done by [12] showed that measuring service quality using perception only scale encapsulates more deviation in service quality than studies based on differences. In addition to this, the performance-based scale reduces the number of items to be measured by half as compared to the disconfirmation scale. So, performance only measure is used in this study. "Automated service quality" is customer's evaluation of services rendered using electronic channels [6]. [13] examined the part that technology plays in Australian banking services. Researchers found six e-banking quality dimensions as efficiency; convenience/accuracy; accessibility; queue management; feedback/complaint management and customisation. [14] proposed 17 factors of e-banking quality as responsiveness, diverse features /product variety, courtesy, reliability, access, competence, credibility, ease of use , communication, aesthetics, understanding the customer, collaboration, accuracy, continuous improvement, content, security and timeliness. Researchers put forward that both electronic bank as well as traditional banks offering e-banking services should focus on reliability, responsiveness and access dimensions. [15] proposed service quality model in Internet banking. They identified the following five dimensions: the image and reputation of the service organization, customer expectations of the service, customer participation, aspects of the service setting and service encounter. Among these factors, customer participation and service setting have the major influence on service evaluation. [4] conducted study to establish the critical determinants of automated service quality by including attributes of three main banking services channel (ATM, Telephone Banking and Internet Banking) along with attributes corresponding to two additional dimensions of Perceived Price and Core Service. The paper proposed a conceptual model of automated banking services quality. Using open-ended exploratory interviews, past studies and quantitative analyses [16] proposed 7 dimensions of Internet banking quality: convenience, auxiliary features, personal finances, security, exploration, investment and status. The researcher made suggestion that banks offering electronic banking services should pay more attention towards young customers. [17] found that there is a direct association between technology and quality of service in banking sector. [18] conducted research on electronic banking in Nigeria. He found the major factors accountable for internet banking. He gave a structure of the factors for assessing the perception about e-banking. Researcher found major factors as queue management, security, accessibility, user friendliness, fund transfer and time. Survey results showed that $88 \%$ respondents were of the opinion that ebanking is flexible and convenient way of banking. [19] proposed dimensions affecting service quality as e- Fulfillment, System availability, efficiency, accuracy, responsiveness, security, convenience, ease to use, problem handling, cost effectiveness, contact and compensation. [3] conducted a research on undergraduate students of a University in the Massachusetts state of the USA and identified service quality dimensions as technology convenience, technology usage easiness and reliability, technology security and information quality, and customer service. 


\subsection{Automated Banking-Customer satisfaction Relationship}

Customer satisfaction refers to post consumption feelings or judgments about a product [20]. In the present study satisfaction is considered as a multi-item construct $[3,21,22]$. Good service quality leads to satisfying relationship with customers [23] and Higher customer satisfaction results in better profits and word-of-mouth recommendation [24,25]. Therefore, studying the relationship of service quality with satisfaction is considered important. The impact of service quality on customer satisfaction was investigated in many studies. In automated banking, customer satisfaction is found to be affected by service quality $[3,21,26]$. But, most of the such studies considered effect of single technology like ATM banking [27,28] and Internet Banking $[22,29,30]$ on customer satisfaction.

A review of the literature uncovers that majority of the automated banking service quality studies covers one electronic banking channel service quality and does not include other important automated banking service channels. So in the present study, broad attributes affecting technology based self service banking (TBSSB) service quality are identified. Considering these attributes, relationship between TBSSB service quality and Customer satisfaction is investigated.

\section{Methodology}

\subsection{Scale Development}

A survey was conducted to in order to study the impact of TBSSB service quality on customer satisfaction. The survey questionnaire constituted questions related to TBSSB service quality attributes and customer satisfaction along with other questions. Table 1 shows 20 items related to TBSSB service quality and 3 items related to customer satisfaction. TBSSB service quality attributes are identified and adapted through a comprehensive review of various studies on automated service quality $[3,13,31,32,33,34,35,36,37,38,39,40,41,42,43,44,45,46,47]$. The items related to customer satisfaction are identified and adapted from $[3,21,22,35,48,49,50]$.

Table 1: Attributes affecting TBSSB service quality and customer satisfaction

\begin{tabular}{|c|l|}
\hline Attribute & \multicolumn{1}{c|}{ Attribute Name } \\
\hline A1 & TBSSB services are able to conduct error free transactions every time \\
\hline A2 & TBSSB services are available 24 x 7 (7 days, 24 hours) \\
\hline A3 & TBSSB give directions to new users \\
\hline A4 & I receive prompt responses to my requests while using TBSSB \\
\hline A5 & TBSSB provides consistent services \\
\hline A6 & TBSSB provides customer feedback services \\
\hline A7 & TBSSB acknowledges me by name \\
\hline A8 & TBSSB provides the precise and sufficient information I need \\
\hline A9 & TBSSB provides product offerings according to my preferences \\
\hline A10 & $\begin{array}{l}\text { TBSSB services provides accurate records of all transactions that have } \\
\text { taken place }\end{array}$ \\
\hline A11 & $\begin{array}{l}\text { I feel secure that my personal information will not be shared with third } \\
\text { party in using TBSSB }\end{array}$ \\
\hline A12 & Financial transactions done using TBSSB are secure \\
\hline A13 & TBSSB services are cost effective \\
\hline
\end{tabular}




\begin{tabular}{|c|l|}
\hline A14 & TBSSB services are easy to use \\
\hline A15 & TBSSB has adequate menu options for everyday banking needs \\
\hline A16 & $\begin{array}{l}\text { Elements of security are incorporated in TBSSB by bank and I am made } \\
\text { aware of them }\end{array}$ \\
\hline A17 & TBSSB services has a user-friendly system \\
\hline A18 & TBSSB gives me more freedom of mobility \\
\hline A19 & When problems occur, the TBSSB system guides me to solve them \\
\hline A20 & TBSSB is less time consuming as compared to branch banking \\
\hline S1 & I am satisfied with TBSSB services of my bank \\
\hline S2 & I am satisfied with the products offered by my bank \\
\hline S3 & Overall I am satisfied with my bank \\
\hline
\end{tabular}

Data was collected using self-administered paper-based questionnaires from the customers of different banks in Delhi and NCR region in India using convenience sampling. Only those customers were considered in the survey that are above 18 years of age and use at least one mode of electronic banking. Out of 600 distributed questionnaires, 440 were received back. Only 414 from 440 responses were usable, resulting in response rate of 69 percent. The respondents were requested to give their response corresponding to items (variables) on a five-point scale, having range from strongly disagree to strongly agree. Respondents' Demographic profile is presented in Table 2.

Table 2: Profile of the respondents

\begin{tabular}{|l|l|r|}
\hline & & \multicolumn{1}{|c|}{ Percent } \\
\hline Gender & Male & 57.00 \\
\hline & Female & 43.00 \\
\hline Age & 18 - up to 25 yrs & 21.50 \\
\hline & More than 25 -up to 35 yrs & 38.40 \\
\hline & More than 35- up to 45 yrs & 30.00 \\
\hline & More than 45 yrs & 10.10 \\
\hline Highest Completed Education & 12th or Below & 2.20 \\
\hline & Graduate & 66.40 \\
\hline & Post Graduate and above & 31.40 \\
\hline Occupation & Student & 12.60 \\
\hline & Salaried & 58.90 \\
\hline & Self employed & 22.50 \\
\hline & Others & 6.00 \\
\hline Annual Income(in INR per annum) & upto 2 Lacs & 21.00 \\
\hline & More than 2- up to 5 Lacs & 39.60 \\
\hline & More than 5- up to 10 Lacs & 30.20 \\
\hline & More than 10 Lacs & 9.20 \\
\hline & Up to 5 times & 54.83 \\
\hline
\end{tabular}




\begin{tabular}{|l|l|r|}
\hline & More than 5 - up to 10 times & 31.40 \\
\hline & More than $10-$ up to 20 times & 10.63 \\
\hline & More than 20 times & 3.14 \\
\hline
\end{tabular}

\section{DAta Analysis AND Results}

For the purpose of analysis, Data sample of 414 was split into two sub-samples of 207 each. SubSample 1 was used for exploratory factor analysis and sub-sample 2 for confirmatory purpose.

\subsection{Exploratory Factor Analysis (EFA)}

Factor analysis was applied to the captured responses corresponding to attributes. Before establishing the factor structure, initially the correlation matrix was checked to find its suitability for factor analysis. The sample size adequacy for factor analysis was determined by KaiserMeyer-Oklin (KMO) value, which is found to be more than 0.6 [51]. Also, the test statistic for sphericity [52] value was found to be big enough. Bartlett's test of sphericity was also significant at low significance level (0.000). In order to extract the factors, Principal Axis Factoring method was used by applying the constraint of higher than one eigen value for each factor [53]. Moreover only variables with loadings of at least 0.5 [54] were included in the analysis.

In the initial exploration, two variables 'TBSSB services provide accurate records for all transactions' and 'TBSSB services are cost effective' were deleted as they were having factor loadings of $<0.5$. The remaining variables are again factors analyzed. The resulting factors satisfactory explained 70.046 percent of the total variance. The extracted factors were then rotated using Varimax rotation method. The dimensions (factors) with corresponding items (variables) and loadings are presented in table 3. Factors Reliability was computed using the Cronbach's alpha and values are shown in table 3. The magnitude of Cronbach's alpha was higher than or equal to 0.7 , which indicated that the factors are reliable [54]. In this study every factor had adequate magnitude of Cronbach's alpha as shown in table 3.

Taking into consideration variables covered under various factors and relevant literature, TBSSB service quality factors are named as Convenience, Reliability and Security, Responsiveness and Personalization. Six variables loaded on factor 1 and were all related to "Convenience". The second factor has five variables which were all related to "Reliability and Security". Third Factor has four variables which are related to "Responsiveness". The forth factor has three items related with the "Personalization" and finally all three items S1, S2 and S3 loaded significantly on a single factor named Customer Satisfaction.

Table 3: TBSSB service quality and Customer Satisfaction rotated factor matrix

\begin{tabular}{|c|l|c|c|}
\hline $\begin{array}{c}\text { Factor Name } \\
\text { (Dimension) }\end{array}$ & \multicolumn{1}{|c|}{ Items (Variables) } & $\begin{array}{c}\text { Factor } \\
\text { Loadings }\end{array}$ & $\begin{array}{c}\text { Cronba } \\
\text { ch's } \\
\text { Alpha }\end{array}$ \\
\hline \multirow{2}{*}{ Convenience } & $\begin{array}{l}\text { TBSSB is less time consuming as compared } \\
\text { to branch banking }\end{array}$ & 0.690 & \multirow{2}{*}{0.889} \\
\cline { 2 - 3 } & & \multirow{2}{*}{0.736} & \\
\cline { 2 - 4 } & TBSSB services are easy to use & & \\
\hline
\end{tabular}




\begin{tabular}{|c|c|c|c|}
\hline & $\begin{array}{l}\text { TBSSB services are available } 24 \text { x } 7 \text { ( } 7 \text { days, } \\
24 \text { hours) }\end{array}$ & 0.699 & \\
\hline & TBSSB gives me more freedom of mobility & 0.793 & \\
\hline & TBSSB services has a user-friendly system & 0.775 & \\
\hline & $\begin{array}{l}\text { TBSSB has adequate menu options for } \\
\text { everyday banking needs }\end{array}$ & 0.601 & \\
\hline \multirow{5}{*}{$\begin{array}{l}\text { Reliability } \\
\text { and Security }\end{array}$} & $\begin{array}{l}\text { Elements of security are incorporated in } \\
\text { TBSSB by bank and I am made aware of } \\
\text { them }\end{array}$ & 0.696 & \multirow{5}{*}{0.919} \\
\hline & $\begin{array}{l}\text { I feel secure that my personal information } \\
\text { will not be shared with third party in using } \\
\text { TBSSB }\end{array}$ & 0.805 & \\
\hline & $\begin{array}{l}\text { TBSSB services are able to conduct error free } \\
\text { transactions every time }\end{array}$ & 0.856 & \\
\hline & TBSSB provides consistent services & 0.820 & \\
\hline & $\begin{array}{l}\text { Financial transactions done using TBSSB are } \\
\text { secure }\end{array}$ & 0.791 & \\
\hline \multirow{4}{*}{$\begin{array}{l}\text { Responsivene } \\
\text { ss }\end{array}$} & TBSSB give directions to new users & 0.681 & \multirow{4}{*}{0.800} \\
\hline & TBSSB provides customer feedback services & 0.641 & \\
\hline & $\begin{array}{l}\text { I receive prompt responses to my requests } \\
\text { while using TBSSB }\end{array}$ & 0.647 & \\
\hline & $\begin{array}{l}\text { When problems occur, the TBSSB system } \\
\text { guides me to solve them }\end{array}$ & 0.722 & \\
\hline \multirow{3}{*}{$\begin{array}{l}\text { Personalizatio } \\
\mathrm{n}\end{array}$} & TBSSB acknowledges me by name & 0.751 & \multirow{3}{*}{0.875} \\
\hline & $\begin{array}{l}\text { TBSSB provides product offerings according } \\
\text { to my preferences }\end{array}$ & 0.853 & \\
\hline & $\begin{array}{l}\text { TBSSB provides the precise and sufficient } \\
\text { information I need }\end{array}$ & 0.828 & \\
\hline
\end{tabular}




\begin{tabular}{|c|l|c|c|}
\hline \multirow{2}{*}{$\begin{array}{c}\text { Customer } \\
\text { Satisfaction }\end{array}$} & $\begin{array}{l}\text { I am satisfied with TBSSB services of my } \\
\text { bank }\end{array}$ & 0.641 & \multirow{2}{*}{0.748} \\
\cline { 2 - 3 } & $\begin{array}{l}\text { I am satisfied with the products offered by } \\
\text { my bank }\end{array}$ & 0.708 & 0.761 \\
\cline { 2 - 3 } & Overall I am satisfied with my bank & \\
\hline
\end{tabular}

\subsection{Confirmatory Factor Analysis (CFA)}

Next objective was to confirm the factor structure using sample 2. AMOS 20.0 software was used to perform the confirmatory factor analysis. Confirmatory factor analysis showed that the variables loaded as per the pattern found during exploratory factor analysis. There are specific measures that can be used test the model fit. As per [56], using three to four fit indices provides sufficient evidence of model fit. The researcher needs to report at least one incremental index and one absolute index, along with value of chi-square and degrees of freedom (df). So, reporting the value of chi-square value and df, Tucker-Lewis Index (TLI) or Comparative Fit Index (CFI) and RMSEA will usually provide adequate unique information to evaluate a model. The fit indices values and acceptable fit criterion of the measurement model were as follows: Chi-square= 251.765, degrees of freedom $(\mathrm{df})=179$, Chi-square/df $=1.407(<3), \mathrm{CFI}=0.973(>0.95)$, RMSEA $=0.044(<0.05)$, TLI $=0.969(>0.95)$. Computed values for measurement model pointed towards the well fitted model.

In addition, all the variables had a significant factor loading on the related factor (latent constructs). Taken together, the measurement model confirmed the structure constituting four factors of TBSSB service quality and one factor of Customer Satisfaction. Confirmatory factor analysis was also performed on the entire data set of 414 responses. Model data fit was confirmed using the results.

\subsubsection{Uni-dimensionality, Reliability and Validity of the model}

\section{Uni-dimensionality}

The dimensionality of the model was tested during EFA by reviewing the loadings of the factors. Each variable had a sufficient loading on the particular factor only. This supported the unidimensionality of the scale [56].

\section{Reliability}

The reliability of the model was checked through Cronbach's alpha [56]. The magnitude of Cronbach's alpha for all the dimensions were higher than the lower threshold acceptable limit of 0.7 [54]. The reliability coefficient values for the factors were as follows: Convenience (0.889), Reliability and Security (0.919), responsiveness (0.8), Personalization (0.875) and Customer Satisfaction (0.748). The value of Cronbach's alpha for the TBSSB service quality and Customer Satisfaction instrument was 0.883, showing that the instrument is reliable. Also, Average Variance Extracted (AVE) as well as Composite reliability (CR) of all the dimensions were more than the acceptable limit of 0.5 and 0.7 respectively [56,57] as shown in table 4 , supporting the reliability of the instrument. 
Table 4: Reliability and Convergent Validity metrics

\begin{tabular}{|c|c|c|}
\hline & Composite Reliability & Average Variance Extracted \\
\hline Customer Satisfaction & 0.808 & 0.585 \\
\hline Reliability \& Security & 0.930 & 0.725 \\
\hline Responsiveness & 0.829 & 0.550 \\
\hline Personalization & 0.917 & 0.788 \\
\hline Convenience & 0.912 & 0.636 \\
\hline
\end{tabular}

\section{Validity}

Validity was tested by examine the face validity, discriminant validity and convergent validity.

Face validity was established by taking the attributes (items) in the study from the existing literature and adapting them.

Convergent validity is the extent to which variables under a factor measure that same factor [56,57]. AVE and factor loadings were used to examine convergent validity as suggested by [57]. All the variables had considerably large loadings on respective factors. Moreover, the AVE for each dimension is higher than 0.50 as shown in table 4 , supporting convergent validity.

Discriminant validity according to [57], evaluates the degree of distinctiveness of measures i.e. correlation between them must not be high that appear to determine the same underlying factors [58]. [57] suggested that the comparison of the AVE with inter-construct squared correlation values can be used to determine discriminant validity.

In the table 5, Diagonal elements in the correlation matrix of constructs were the square root of the AVE values and off diagonal elements represented inter-construct correlations. The diagonal elements were greater than the off diagonal, supporting the discriminant validity of the constructs.

Table 5: Discriminant validity

\begin{tabular}{|l|c|c|c|l|c|}
\hline & $\begin{array}{c}\text { Customer } \\
\text { Satisfaction }\end{array}$ & $\begin{array}{c}\text { Reliability } \\
\text { \& } \\
\text { Security }\end{array}$ & $\begin{array}{c}\text { Responsi } \\
\text { veness }\end{array}$ & $\begin{array}{l}\text { Personalizatio } \\
\mathbf{n}\end{array}$ & Convenience \\
\hline $\begin{array}{l}\text { Customer } \\
\text { Satisfaction }\end{array}$ & 0.765 & & & & \\
\hline $\begin{array}{l}\text { Reliability \& } \\
\text { Security }\end{array}$ & 0.278 & 0.852 & & & \\
\hline Responsiveness & -0.02 & 0.019 & 0.741 & & \\
\hline Personalization & 0.606 & 0.239 & -0.049 & 0.888 & \\
\hline Convenience & 0.398 & 0.419 & -0.018 & 0.346 & 0.798 \\
\hline
\end{tabular}

\subsubsection{Impact of TBSSB service quality dimensions on customer satisfaction}

The proposed structural model is shown in figure 1. The overall fit indices and acceptable fit criterion for the proposed structural model were as follows: Chi-square $=251.765$, degrees of freedom $(\mathrm{df})=179$, Chi-square $/ \mathrm{df}=1.407(<3), \mathrm{CFI}=0.973(>0.95)$, RMSEA $=0.044(<0.05)$, TLI $=0.969(>0.95)$. All computed values confirmed the fitness of the model. Hypotheses were tested by using the structural equation modelling (SEM) using AMOS 20.0. To study the effect of 
Technology based self service banking quality on customer satisfaction following four hypotheses were tested

H1. Convenience has a direct positive influence on customer satisfaction.

H2. Reliability \& Security has a direct positive influence on customer satisfaction

H3. Responsiveness has a direct positive influence on customer satisfaction

H4. Personalization has a direct positive influence on customer satisfaction

Table 6: Standardised regression weights and the significance level for hypothesised paths

\begin{tabular}{|l|c|c|}
\hline Relation between Constructs & $\begin{array}{c}\text { Standardized Regression } \\
\text { Weights }\end{array}$ & $\begin{array}{c}\text { Significance } \\
\text { Level }\end{array}$ \\
\hline Convenience $\rightarrow$ Satisfaction & $0.186 * *$ & 0.018 \\
\hline Reliability \& Security $\rightarrow$ Satisfaction & $0.075(\mathrm{NS})$ & 0.311 \\
\hline Responsiveness $\longrightarrow$ Satisfaction & $0.008(\mathrm{NS})$ & 0.911 \\
\hline Personalization $\longrightarrow$ Satisfaction & $0.524 * * *$ & $* * *$ \\
\hline
\end{tabular}

NS implies "not significant"; $* *$ Implies significant at $\mathrm{p}<0.05 ; * * *$ Implies significant at $\mathrm{p}<$ 0.001

Examination of the path coefficients and the significance level between the constructs in the model were used to test the hypotheses. The analysis in table 6 shows that Convenience and Personalization dimension have a positive significant relationship with customer satisfaction. Thus, H1 and H4 are supported. But, Responsiveness and Reliability \& Security dimensions do not have significant positive relation with customer satisfaction. Thus, $\mathrm{H} 2$ and $\mathrm{H} 3$ are not supported.

\section{CONCLUSION}

In this paper, attempt is made to study the impact of TBSSB service quality dimensions on customer satisfaction. In total 23 attributes affecting TBSSB service quality and customer satisfaction are considered for the purpose of evaluation. To study the impact, firstly key dimensions of TBSSB service quality and customer satisfaction are explored by conducting study on 414 Indian retail banking customers using structured questionnaire. Data sample of 414 was split into two equal sub-samples. Sample 1 is used for EFA to identify dimensions and sample 2 is used for CFA to confirm the factor structure. Analysis revealed and confirmed four dimensions of TBSSB service quality, named as Convenience, Reliability and Security, Responsiveness, Personalization and one dimension of customer satisfaction. The proposed factor structure of TBSSB service quality showed evidence of uni-dimensionality, reliability, face validity, convergent validity and discriminant validity. Moreover, various criteria indices for the model have also been found to exceed the obligatory requirements. Four hypotheses were tested to investigate the relationship between TBSSB service quality and Customer Satisfaction employing SEM. Result of hypotheses testing showed that Convenience and Personalization dimension have a positive significant relationship with customer satisfaction. But, the relation of Responsiveness and Reliability \& Security dimensions with customer satisfaction is not significant. So, TBSSB service quality can be said to have weak influence on customer satisfaction. The findings of the study may act as input for banks, so that they may focus on those aspects of technology based self service banking which may enhance customer satisfaction, ultimately resulting in customer loyalty and higher profitability. The same method for establishing relationship between service quality and customer satisfaction can also be used for other multi mode technology based services like share and commodity trading by considering their broad self service technology attributes. 


\section{REFERENCES}

[1] Joshua, A. J. (2009), “Adoption of Technology Enabled Banking Self Services antecedents and consequences".

[2] Hallowell, R. (1996), "The relationships of customer satisfaction, customer loyalty and profitability", International Journal of Service Industries Management, Vol. 7 No. 4, pp. 27-42.

[3] Ganguli, S., \& Roy, S. K. (2011). "Generic technology-based service quality dimensions in banking: Impact on customer satisfaction and loyalty”,International Journal of Bank Marketing, 29(2), 168189.

[4] Al-Hawari, M., Hartley, N. and Ward, T. (2005), "Measuring banks' automated service quality: a confirmatory factor analysis approach", Marketing Bulletin, Vol. 16, May, pp. 1-19.

[5] Seth,N., Deshmukh,S.G., Prem Vrat, (2006) "A conceptual model for quality of service in the supply chain", International Journal of Physical Distribution \& Logistics Management, Vol. 36 ,No. 7, pp. $547-575$.

[6] Santos J. (2003), "E-service quality: a model of virtual service quality dimensions" Managing Service Quality, 13(3), 233-246.

[7] Gronroos, C.(1984) "A Service Quality Model and its marketing implications", European Journal of Marketing, Vol. 18, No. 4, p36-44.

[8] Parasuraman, A., Zeithaml, V.A. and Berry, L.L. (1985), "A conceptual model of service quality and its implications for future research", Journal of Marketing, Vol. 49 No. 4, pp. 41-50.

[9] Parasuraman, A., Zeithaml, V.A. and Berry, L.L. (1988), "SERVQUAL: a multiple-item scale for measuring consumer perceptions of service quality", Journal of Retailing, Vol. 64 No. 1, pp. 12-40.

[10] Cronin, J. J. Jr. and Taylor, S. A. (1994), "SERVPERF Versus SERVQUAL : Reconciling Performance Based and Perceptions Minus Expectations Measurement of Service Quality", Journal of Marketing, Vol.58, January, pp.125-131

[11] Page, T. J., Spreng, R. A. (2002), "Difference Scores Versus Direct Effects in Service Quality Measurement", Journal of Service Research, Vol. 4,No 3, p184-93.

[12] Lee, H., Lee, Y. and Yoo, D. (2000), "The determinants of perceived service quality and its relationship with satisfaction", Journal of Services Marketing, Vol.14, No. 3, pp 217-231.

[13] Joseph, M., McClure, C. and Joseph, B. (1999), "Service quality in the banking sector: the impact of technology on service delivery", International Journal of Bank Marketing, Vol. 17 No. 4, pp. 182-91.

[14] Jun, M. and Cai, S., (2001), "The determinants of internet banking service quality: A content analysis" ,Internetional journal of Bank marketing, Vol. 19 No. 7, pp 276-291

[15] Broderick, A. J., \& Vachirapornpuk, S. (2002). Service quality in internet banking: the importance of customer role. Marketing Intelligence \& Planning,20(6), 327-335.

[16] Mäenpää, K. (2006). Clustering the consumers on the basis of their perceptions of the Internet banking services. Internet Research, 16(3), 304-322.

[17] Ombati, T.O., Magutu, P.O., Nyamwange, S.O., and Nyaoga, R.B.,(2010), Technology andservice quality in the banking industry, African Journal of Business \& Management, vol. 1, pp. 1-16.

[18] Auta E M (2010), e-banking in developing economy: empirical evidence from nigeria", Journal of applied quantitative methods, Vol. 5, No.2.

[19] Kumbhar, V.M. (2011), Structural equation modeling of eBankQual scale: a study of E-Banking in India, International Journal of Business Economics and Management Research, Vol. 2, Iss. 5, pp. 1832.

[20] Jamal, A. \& Naser, K. (2003). "Factors influencing customer satisfaction in the retail banking sector in Pakistan". International Journal of Commerce \& Management, 13(2): 29-53.

[21] Al-Hawari, M., \& Ward, T. (2006). "The effect of automated service quality on Australian banks' financial performance and the mediating role of customer satisfaction". Marketing Intelligence \& Planning, 24(2), 127-147.

[22] Rod, M., Ashill, N. J., Shao, J., \& Carruthers, J. (2009), “An examination of the relationship between service quality dimensions, overall internet banking service quality and customer satisfaction: A New Zealand study", Marketing Intelligence \& Planning, 27(1), 103-126.

[23] Lassar, W., Manolis, C., \& Winsor, R. (2000). "Service quality perspective and satisfaction in private banking". International Journal of Bank Marketing, 14(3): 244- 271.

[24] Beerli, A., Martin, 1, \& Quintana, A. (2004). "A model of customer loyalty in the retail banking market". European Journal of Marketing, 38(112): 253-275.

[25] Reichheld, F. (1996). The loyalty effect. Harvard Business School Press Boston, MA 
[26] Kumbhar, V. M. (2011), “Alternative Banking Channels and Customers' Satisfaction: An Empirical Study of Public and Private Sector Banks", International Journal of Business and Management Tomorrow, 1(1).

[27] Islam, R., Kumar, S., \& Biswas, P. K. (2007), "Customer satisfaction of ATM service: a case study of HSBC ATM", Available at SSRN 990242.

[28] Kumbhar, v. M. (2011), “Customers'satisfaction in ATM service: an empirical evidences from public and private sector banks in india", Management research and practice, 3(2), 24-35.

[29] AlSudairi, M. A. T. (2012), "E-Service Quality Strategy: Achieving Customer Satisfaction in Online Banking", Journal of Theoretical and Applied Information Technology, 38(1).

[30] Zavareh, F. B., Ariff, M. S. M., Jusoh, A., Zakuan, N., Bahari, A. Z., \& Ashourian, M. (2012), "Eservice quality dimensions and their effects on e-customer satisfaction in internet banking services", Procedia-Social and Behavioral Sciences, 40, 441-445.

[31] Joseph, M. and Stone, G. (2003), “An empirical evaluation of US bank customer perceptions of the impact of technology on service delivery in the banking sector", International Journal of Retail \& Distribution Management, Vol. 31 No. 4, pp. 190-202.

[32] Ibrahim, E. E., Joseph, M., \& Ibeh, K. I. (2006). Customers' perception of electronic service delivery in the UK retail banking sector. International Journal of Bank Marketing, 24(7), 475-493.

[33] Doll, W.J. and Torkzadeh, G. (1988), "The measurement of end-user computing satisfaction", MIS Quarterly, Vol. 12 No. 2, pp. 259-74.

[34] Van Riel, A.C.R., Liljander, V. and Jurriens, P. (2001), "Exploring consumer evaluations of eservices: a portal site", International Journal of Service Industry Management, Vol. 12 No. 4, pp. 35977.

[35] Yang, Z., Joon, M. and Peterson, R.T. (2004), "Measuring customer perceived online service quality: scale development and managerial implications", International Journal of Operations \& Production Management, Vol. 24 No. 11, pp. 1149-74.

[36] Al-Hawari, M. A. (2011). Automated service quality as a predictor of customers' commitment: a practical study within the UAE retail banking context. Asia Pacific Journal of Marketing and Logistics, 23(3), 346-366.

[37] Sahadev, S., \& Purani, K. (2008). Modelling the consequences of e-service quality. Marketing Intelligence \& Planning, 26(6), 605-620.

[38] Meuter, M.L., Ostrom, A.L., Roundtree, R.I. and Bitner, M.J. (2000), "Self-service technologies: understanding customer satisfaction with technology-based service encounters", Journal of Marketing, Vol. 64 No. 3, pp. 50-64.

[39] Bauer, H.H., Hammerschmidt, M. and Falk, T. (2005), "Measuring the quality of e-banking portals", International Journal of Bank Marketing, Vol. 23 No. 2, pp. 153-75.

[40] Ho, C.B. and Lin, W. (2010), "Measuring service quality of internet banking: scale development and validation", European Business Review, Vol. 22 No. 1, pp. 5-24.

[41] Narteh, B. (2013). Service quality in automated teller machines: an empirical investigation. Managing Service Quality, 23(1), 62-89.

[42] Sureshchandar, G., Rajendran, C. and Anantharaman, R. N. (2002). "Determinants of customer perceived service quality: A confirmatory factor analysis approach.” Journal of Services Marketing, Vol. 16, No 1, pp 9-34.

[43] Katono, I.W. (2011), "Construction of an instrument to measure social valuation in an emerging market context”, Education and Training, Vol. 53 No. 5, pp. 371-86.

[44] Parasuraman, A., Zeithaml, V.A. and Malhotra, A. (2005), "E-S-QUAL: a multiple-item scale for assessing electronic service quality”, Journal of Service Research, Vol. 7 No. 3, pp. 213-33.

[45] Dabholkar, P. and Bagozzi, R.P. (2002), "An attitudinal model of technology-based self-service: moderating effects of consumer traits and situational factors", Journal of the Academy of Marketing Science, Vol. 30 No. 3, pp. 184-201.

[46] Dilijonas, D., Kriksciunien, D., Sakalauskas, V. and Simutis, R. (2009), "Sustainability based service quality approach for automated teller machine network", available at: www.vgtu.lt/leidinai/leidykla/KORSD_2009/PDF/241-246-p100-Dilijonas-47.pdf $\quad$ (accessed 14 November 2009).

[47] Parasuraman, A. (2000), "Technology readiness index (TRI): a multiple-item scale to measure readiness to embrace new technologies", Journal of Service Research, Vol. 2 No. 4, pp. 307-20.

[48] Ganesh, J., Arnold, M.J. and Reynolds, K.E. (2000), "Understanding the customer base of service providers: an examination of the differences between switchers and stayers", Journal of Marketing, Vol. 64 No. 3, pp. 65-87. 
[49] Krepapa, A., Berthon, P., Webb, D. and Pitt, L. (2003), "Mind the gap: an analysis of service provider versus customer perceptions of market orientation and the impact on satisfaction", European Journal of Marketing, Vol. 37 Nos 1/2, pp. 197-218.

[50] Woo, K.S. and Fock, H.K.Y. (1999), "Customer satisfaction in the Hong Kong mobile phone industry”, The Service Industries Journal, Vol. 19 No. 3, pp. 162-74.

[51] Kaiser, H. F. (1974), “An index of factorial simplicity” Psychometrika, 39(1), 31-36.

[52] Bartlett, M. S. (1954), "A note on the multiplying factors for various $\chi 2$ approximations", Journal of the Royal Statistical Society. Series B (Methodological), 296-298.

[53] Malhotra, N. and Birks, D. (2007), Marketing Research. An Applied Approach, Prentice Hall, London.

[54] Hair, J.F. Jr, Black, C.W., Babin, J.B., Anderson, R.E. and Tatham, L.R. (2006), Multivariate Data Analysis, 6th ed., Prentice-Hall, Upper Saddle River, NJ.

[55] Costello, Anna B. \& Jason Osborne (2005). Best practices in exploratory factor analysis: four recommendations for getting the most from your analysis. Practical Assessment Research \& Evaluation, 10(7).

[56] Hair, J.F. Jr, Black, C.W., Babin, J.B., Anderson, R.E. and Tatham, L.R. (2010), Multivariate Data Analysis, 7th ed., Prentice-Hall.

[57] Fornell, C. and Larcker, D.F. (1981), "Evaluating structural equation models with unobservable variables and measurement error", Journal of Marketing Research, Vol. 18 No. 3, pp. 375-81.

[58] Siekpe, S.J. (2005), “An examination of the multidimensionality of the flow construct in a computermediated environment", Journal of Electronic Commerce Research, Vol. 6 No. 1, pp. 31-43.

\section{Authors}

\section{Rajiv Sindwani}

Rajiv Sindwani is working as assistant professor in Department of Management Studies at YMCA Universityof Science and Technology, Faridabad, India. He is having total 10 years of experience in various sectors including consumer durables, banking and education. Currently, he is doing research in the area of service quality in technology based self service banking. He has authored papers in national and international journals.

\section{Dr Manisha Goel}

Manisha Goel holds a PhD degree in management. She has authored many papers in international journals. With more than 13 years of teaching and research experience, currently she is working as Associate Professor in Department of Management Studies at YMCA University of Science and Technology, Faridabad, India.
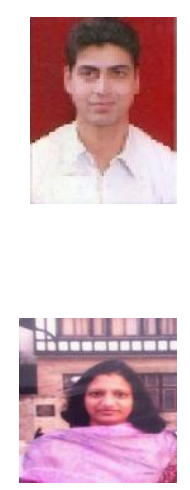


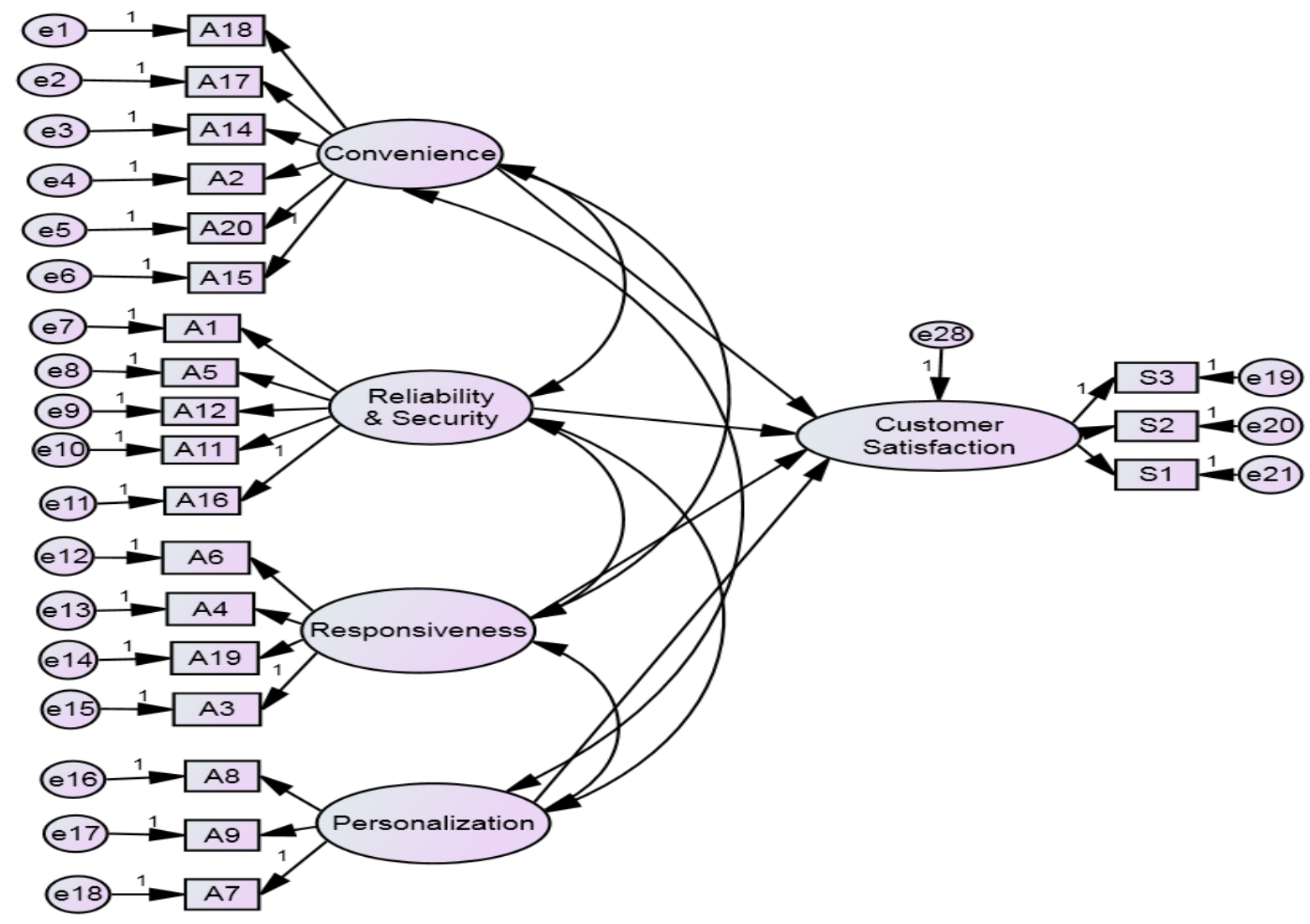

Figure 1. Model showing relationship between TBSSB service quality and Customer Satisfaction 